\title{
PROSPECTS OF STUDYING OF VOLATILE OILS OF TANACETUM PARTHENIUM (L.) SCHULTZ BIP. FOR ISSUES IN CHEMOSYSTEMATICS OF TANACETUM GENUS
}

\author{
Karyna Hordiei \\ Department of Botany ${ }^{1}$ \\ Tetiana Gontova \\ Department of Botany ${ }^{1}$ \\ Valentina Gaponenko \\ Department of Botany ${ }^{1}$ \\ ${ }^{I}$ National University of Pharmacy \\ 53 Pushkinska str., Kharkiv, Ukraine, 61002
}

\begin{abstract}
The search for new sources of biologically active substances is an actual issue of pharmaceutical science. Feverfew is a prospective member of the Tanacetum genus. Recently an interest to this plant has grown. Sesquiterpene lactones and phenolic compounds are known to be cause its anti-inflammatory and antimigraine activity. The study of volatile compounds and chemosystematics of the feverfew in this group of BAS has not been conducted before.

The aim of the research was to obtain the volatile oil from the feverfew herb, studying of the component composition, an identification of compounds, that can be used for chemosystematics of the genus and establishing of the pharmacological activity according to the chemical content of volatile oil.

Materials and methods. The object of research was the samples of the feverfew herb grown and collected in the period of its mass flowering. The volatile oil obtained by steam distillation from the feverfew herb was studied using gas chromatography - mass spectrometry.

Results. The comparative characteristic of the representatives of the genus Tanacetum according to chemosystematic features was carried out. As a result of the research of the volatile oil 44 compounds were found, from which 40 were identified. According to the research, the raw material contained $34.71 \%$ of camphor, this is a typical feature of all species of the genus Tanacetum. Fenchyl acetate was identified in a high enough content $-7.44 \%$ in the domestic raw material, but this compound was not identified in the foreign samples. Chrysanthenyl acetate is accumulated in representatives of the genus Tanacetum in the form of a cis or trans isomer. In our study, the content of trans-chrysanthene acetate was $23.30 \%$. In the domestic raw materials, monoterpenes - $\alpha$ - and $\beta$ - thujone - were not identified, which are associated with the toxicity of the raw material.

Conclusions. In the volatile oil 44 compounds were found, from which 40 were identified. Monoterpenes prevailed among terpenes, namely camphor, trans-chrysanthenyl acetate and fenchyl acetate, which are typical and can be used for chemosystematic issues of the genus Tanacetum.

The identified compounds require anti-inflammatory, antiseptic, antispasmodic, analgesic activities of the volatile oil, therefore creation of the medicinal herbal remedy based on the volatile oil of the feverfew herb is prospective.

Keywords: Tanacetum parthenium, herb, volatile oils, gas chromatography-mass spectrometry, chrysanthenyl acetate, camphor, fenchyl acetate.
\end{abstract}

\section{Introduction}

Nowadays a systematic position of a species, genera, families is an actual issue. One of the ways of solving this problem is using of chemical compounds of a certain nature. For this purpose scientists research phenolic compounds (flavonoids, hydroxycinnamic acids), iridoids, volatile oils, etc [1].

Tanacetum genus is one of the biggest in the tribe Anthemideae of the Aster family, it includes about 150-200 species, most of which have specific flavour, that is due to accumulation of volatile oils, mostly in leaves and flowers. Morphological features of members of this genus are different, so there is no unified classification [2]. For example, feverfew (Tanacetum parthenium L. Schultz bip.) is a perennial herbaceous plant of the Aster family, is also known as Chrysanthemum 
parthenium (L.) Bernh., Leucanthemum parthenium (L.) Gren and Gordon, Pyrethrum parthenium (L.) Smith, Matricaria eximia Hort., Matricaria parthenium (L.) Smith. previously belonged to the separate Pyrethrum Zinn genus, which is excluded from the scientific classification according to the recent data. Tanacetum parthenium species is included to Tanacetum genus due to the feature, that unites this plant with the genus, is a presence of white and pink ray flowers in an anthodium [3]. Nowadays the difficulties in ordering of species of genuses Tanacetum and Chrysanthemum are occurred, this is connected to a similarity of morphological features and their chemical content. Different biologically active substances, for example, phenolic compounds and terpenoids are used as markers in the chemosystematics. Chemosystematic analysis of the species is actual for solving of contentious issues. The most studied members of genus Chrysanthemum are florist's daisy (Chrysanthemum morifolium Ramat.) and Indian chrysanthemum (Chrysanthemum indicum L.). The research on the florist's daisy from Nigeria identified the biggest content of such terpenes as cis-chrysanthenyl acetate $(21.6 \%)$, borneol $(15.5 \%)$ in flowers and borneol $(20.5 \%)$, 1.8-cineole $(15.2 \%)$, trans- $\alpha$-bergamotene (14.0\%), camphor (10.6\%) and $\alpha$-pinene $(9.3 \%)$ in leaves [4]. The research on the Chrysanthemum trifurcatum (Desf.) from Tunisia determined in the most quantity such terpenes as limonene (26.63\%), $\alpha$-terpinen (19.68\%), a-pinene (9.7\%) and a-terpenyl acetate (7.16 \%) [5]. The «irregular» structure of synthesis of monoterpenes characterize Tanacetum genus, the main result of this condensation is chrysanthemic acid. Then specific «irregular» monoterpenes are synthesized depending on the position of cycle disclosure (thujone, chrysanthenyl acetate, etc.). The most studied species of this genus is the tansy (Tanacetum vulgare L.) - an aromatic plant, that is widely spread in European, Asian countries and North America. An intraspecies variation of terpenes of volatile oil is typical for this species, with concentration of the main compounds, such as germacrene D, $\beta$-thujone, camphene, eugenol, sabinen from 41 to $99 \%$. In different countries variations of chemotypes occur. For example, for the tansy, which was grown in Hungary is characterized by the chemotype with such compounds: artemisia ketone, artemisia alcohol, y-campholenol, davanone, lyratol, lyratyl acetate, 4-thujen-2a-yl-acetate; in Northern Italy - chrysanthenyl acetate, $\beta$-thujone, terpinen-4-01, myrtenol, artemisia ketone, bornyl acetate; in Finland - sabinene, thujone, umbellulone, camphor, bornyl acetate, a-pinene, 1.8-cineole and germacrene D. As a result of the research of the tansy from Argentina pure chemotype of $\beta$-thujone was identified, its content was $92 \%$ of volatile oil, so the raw material from this region is considered to be a source for obtaining this compound. Species of Tanacetum genus are classified in groups which are based on the molecular terpenoid type of the main component of volatile oils depending on variability of terpene compounds of volatile oils. Monoterpenoid group includes such species as Tanacetum vulgare L., Tanacetum parthenium (L.) Schultz Bip., Tanacetum microphyllum DC. and Tanacefum boreale Fisch [1].

Special compounds of volatile oils for certain species of this genus are «pyrethrin», well known for their insecticide activity. Such species are Tanacetum cinerariifolium (Trev.) Schultz Bip., Tanacefum odessanum (Klok.) Tzvel. And Tanacetum parthenium L. Schultz bip. [1]. «Pyrethrin» are concentrated in flowers and seeds of plants in the most quantity. They are widely used as natural insecticides, which have a higher safety profile in comparison with synthetic insecticides [6].

A research on the domestic members of Tanacetum genus and identification of the main chemotypes of volatile oils is actual. Previously an analysis of volatile oil compounds in leaves and flowers of Tanacetum vulgare L. was conducted. In all the parts ketones, alcohols and saturated hydrocarbons prevailed. The main chemotypes were identified: cys-carvyl acetate, trans-carvyl acetate, $\beta$-thujone, caryophyllene oxide, ledene oxide, trans-carveol, thymol [1].

Prospects of studying of volatile oils are an occurrence of pharmacological effects: antiseptic, bactericidal, analgesic, sedative etc. An opportunity for accumulation of volatile oils in secretory tissue is not equal in all the plants. Many members of such families as Lamiaceae, Asteraceae, Apiaceae, Lauraceae, Myrtaceae are well-known as sources of volatile oils. The quantity of volatile oils in plants could vary from thousandths of a percent to $25 \%$. Search and studying cultivated species from Ukraine and all over the world, which could be used for creating new medicinal plant remedies prompted us to study feverfew (Fig. 1).

The plant is included into many pharmacopoeias of the world, namely into European, British, USP, American Herbal pharmacopoeia and the State Pharmacopeia of Ukraine. In folk medicine 
herb and volatile oil of the feverfew is widely used for treatment and prevention of migraine, inflammatory conditions of connective tissues, dermatosis, allergic and gynaecologic conditions [2]. The recent scientific researches indicate that the main compounds of volatile oil of the feverfew are derivates of bicyclic monoterpenes - camphor and chrysanthenyl acetate. Health benefits of camphor are known since ancient times. It is a strong antiseptic and repellent. Camphor is used for the curative purpose for muscular strains, sprains, inflammatory conditions of connective tissues, rheumatic conditions [7]. Chrysanthenyl acetate was first identified in species Tanacetum boreale Fisch., it is the main marker of volatile oil of Tanacetum genus member. This compound has high antibacterial activity concerning many bacterial causative agents, including causative agents of pneumonia and analgesic activity due to inhibition of synthesis of prostaglandins. Also it is known that chrysanthenyl acetate is used for treatment and prevention for Parkinson's disease.

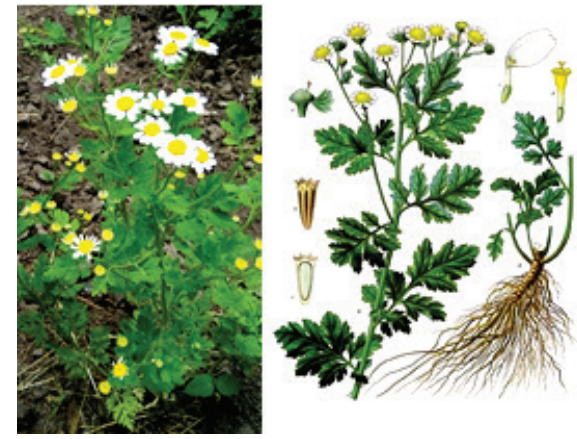

Fig. 1. General view of the living plants and drawing of Tanacetum parthenium (L.) Schultz Bip.

Previously we conducted the morphological and anatomical analysis of the feverfew herb, which has shown the existence of the excretory glands that contain volatile compounds [8].

The aim of the research was the obtaining of volatile oil from the feverfew herb, studying of its content, an identification of the compounds, that could be used for chemosystematics of the genus and establishing of the pharmacological profile on the chemical content of volatile oil.

\section{Materials and methods}

The object of the research was samples of Tanacetum parthenium herb collected in the period of mass flowering in M. M. Gryshko National Botanical Garden of Ukraine. The analysis of the volatile oil of the feverfew herb had been performed using chromatography-mass spectrometer Agilent Technology HP6890 GC with mass spectrometric detector 5973N [9].

«Agilent» $22 \mathrm{ml}$ vials had been used for distilling of essential oil. Volatile compounds had been washed from the condenser to vial by pentane and concentrated by blowing with nitrogen.

The analysis conditions: quartz and capillary chromatographic column HP-5MS. A length of column $-30 \mathrm{~m}$, an internal diameter $-0.25 \mathrm{~mm}$, carrier gas - helium, a speed of carrier gas $1 \mathrm{ml} / \mathrm{min}$. The injection of $2 \mu \mathrm{l}$ of sample was performed in a mode splitless. The temperature of detector and evaporators $-250{ }^{\circ} \mathrm{C}$. An internal standard - tridecane. The content of essential oil in total content had been calculated in relation to it [10].

Identification of components

For the identification of components, data from the mass spectra libraries NIST05 and WILEY 2007 with a total number of spectra of more than 470.000 were used, combined with the identification programs AMDIS and NIST.

\section{Results}

The results of the research of volatile oils compounds of the T. parthenium herb are shown in the Table 1. 44 components, from which 40 were identified, were found in the volatile oils of the feverfew herb. The majority of components was presented by ketones, alcohols, ethers and unsaturated hydrocarbons. Having analysed the chemical composition of the identified compounds monocyclic (4 compounds) and bicyclic monoterpenes (12 compounds), acyclic diterpene (phytol), 
triterpen (squalene), aliphatic ( $\beta$-farnesene), monocyclic ( 2 compounds), bicyclic (5 compounds) and tricyclic sesquiterpenes ( 2 compounds), aromatic terpenes (6 compounds) and saturated alkanes (5 compounds) were found.

Table 1

Percentage chemical composition of the essential oil of the Tanacetum parthenium (L.) Schultz Bip. Herb

\begin{tabular}{|c|c|c|}
\hline Compound & Retention time, min & Percentage, $\%$ \\
\hline Tricyclene & 4.89 & 0.12 \\
\hline$\alpha$-Pinene & 5.08 & 0.07 \\
\hline Camphene & 5.39 & 1.43 \\
\hline$\beta$-Pinene & 6.13 & 0.12 \\
\hline p-Cymene & 7.39 & 0.91 \\
\hline$\gamma$-Terpinene & 8.49 & 0.36 \\
\hline Camphor & 11.91 & 34.71 \\
\hline Pinene-3-on & 11.96 & 0.24 \\
\hline$*$ & 12.02 & 0.19 \\
\hline Borneol & 12.13 & 0.55 \\
\hline Terpene-4-ol & 12.40 & 0.83 \\
\hline Isoborneol & 12.65 & 2.29 \\
\hline p-Cumene-8-ol & 13.45 & 0.35 \\
\hline Terpineol & 13.59 & 0.48 \\
\hline trans-Chrysanthenyl acetate & 14.82 & 23.30 \\
\hline Fenchyl acetate & 15.86 & 7.44 \\
\hline Thymol & 16.04 & 0.44 \\
\hline Carvacrol & 16.31 & 0.40 \\
\hline$*$ & 17.25 & 0.81 \\
\hline Eugenol & 17.75 & 1.21 \\
\hline$*$ & 17.89 & 0.33 \\
\hline Muurolene & 18.39 & 0.45 \\
\hline Methyl eugenol & 19.00 & 0.30 \\
\hline trans-Caryophyllene & 19.96 & 2.36 \\
\hline Humulene & 20.89 & 0.30 \\
\hline$\beta$-Farnesene & 21.19 & 1.78 \\
\hline Germacrene D & 21.69 & 1.05 \\
\hline$\beta$-Selinene & 21.86 & 0.79 \\
\hline Limonen-6-ol pivalate & 22.43 & 0.58 \\
\hline Isobornyl 3-methanoate & 22.66 & 1.03 \\
\hline$\delta$-Cadinene & 22.94 & 0.21 \\
\hline Bornyl pentanoate & 23.98 & 2.34 \\
\hline$*$ & 24.13 & 0.89 \\
\hline Caryophyllene oxide & 24.56 & 5.42 \\
\hline Globulol & 25.39 & 1.85 \\
\hline Epi-Globulol & 26.49 & 1.85 \\
\hline Phytol & 34.02 & 0.68 \\
\hline Tricosane & 36.09 & 0.22 \\
\hline Tetracosane & 36.83 & 0.05 \\
\hline Pentacosane & 37.12 & 0.09 \\
\hline Hexacosane & 38.14 & 0.49 \\
\hline Heptacosane & 39.99 & 0.13 \\
\hline Squalene & 40.98 & 0.45 \\
\hline Nonacosane & 41.73 & 0.11 \\
\hline
\end{tabular}

Note: the symbol «*» means that the compound was not identified 
The total amount of the compounds was $1375.02 \mathrm{mg} / \mathrm{kg}$. Monoterpenes (36.4\%), sesquiterpenes $(22.7 \%)$ and aromatic terpenes $(13.6 \%)$ were prevailed in the percentage content of the total amount of compounds.

Bicyclic compounds dominated by quantitative content among sesquiterpenes. Among them caryophyllene oxide, trans caryophyllene and $\beta$-selinene in the most quantity accumulated.

Among aromatic terpenes eugenol $(1.21 \%)$ and p-cymene $(0.91 \%)$ were contained in the most quantity.

In much smaller quantity diterpene phytol $(0.68 \%)$, triterpene squalene $(0.45 \%)$ and saturated alkanes were identified, which content ranged from 0.05 to $0.49 \%$. Foreign researchers did not identify these compounds.

\section{Discussion}

Among monoterpenes in the largest number were bicyclic monoterpenes, dominant components of which were camphor $(34.71 \%)$, chrysanthenyl acetate $(23.30 \%)$ and fenchyl acetate $(7.44 \%)$. Foreign researches of the feverfew herb demonstrates the most content of camphor in comparison with other compounds. For example, in the samples of the feverfew herb from Iran was $53.8 \%$ [11]. The study of volatile oil of the feverfew roots from Iran also showed the accumulation of camphor $(30.2 \%)$. According to the results of our research, the raw material contained $34.71 \%$ of camphor, which is a high enough percentage compared with the results of foreign researchers.

Chrysanthenyl acetate is accumulated in the species of genus Tanacetum in form of cis- or trans-isomer. For example in the samples from Iran it had ketone form as chrysanthenone and its amount was $3.3 \%$ [11]. However, in Turkey it was $26.5 \%$ [12]. In our research a content of trans-chrysanthenyl acetate was $23.30 \%$.

Fenchyl acetate of the feverfew in a high enough content $-7.44 \%$ was identified in the domestic raw material, but in the foreign samples this compound was not identified [13].

Our researches confirmed the data of foreign scientists that bicyclic monoterpene camphen, which is a typical for this species, is accumulated in the feverfew herb. Its content was $1.43 \%$ that is slightly less in comparison with a previous research from Iran [11].

The oxide form of caryophyllene is quite difficult to identify using steam distillation. According to the literature sources of the different scientists' groups trans caryophyllene was identified, its content was $5.9 \%$ [14]. Domestic raw material of the feverfew herb contained a high enough percentage of these compounds. The content of caryophyllene oxide was $5.42 \%$, trans caryophyllene $-2.36 \%$, $\beta$-selinene $-0.79 \%$.

In the domestic raw material monoterpenes $-\alpha$ - and $\beta$ - thujone, with which the toxicity of raw material is associated were not identified, unlike to the researches from Iran where the content of $\alpha$-thujone was $0.9 \%$ [14]. A high enough content of bornyl pentanoate $-2.34 \%$ was identified, but the content of this compound from Iran was 7.8 times less ( $0.3 \%)$ [11]. According to the literature sources bornyl acetate is accumulated in a large quantity in the feverfew herb (from $3.1 \%$ to $18.35 \%$ ), but in the domestic raw material this compound was not identified.

Study limitations. Since the calculation of the quantitative content was carried out by the method of normalization, the results of the study may differ slightly from the actual number of compounds in the raw material. It is reasonable to carry out a quantitative determination of identified compounds in comparison with the corresponding standard samples. For better understanding of the process of accumulation of the volatile compounds, it is reasonable to study their accumulation depending on the phase of the growing season, and to study the influence of climatic factors on the qualitative composition and quantitative content of volatile compounds.

Prospects for further researches. Given the wide variety identified volatile compounds in the feverfew herb during the analysis, it is relevant and promising to create herbal medicines based on essential oil and study their pharmacological activity.

\section{Conclusions}

Qualitative and quantitative analysis of the components of the essential oil of T. parthenium from Ukraine was conducted for the first time. Feverfew herb is characterized by the high content 
of essential oil, distinguished by a rich chemical composition. 44 volatile components of the essential oil of feverfew herb were found. Monoterpenes prevailed among terpenes, namely camphor, trans-chrysanthenyl acetate and fenchyl acetate.

Given the significant number of members of the genus Tanacetum, it is possible to use studies of the qualitative composition and quantitative content of essential oil components as additional chemosystematic confirmation of the feverfew to the genus Tanacetum by comparing their component composition with literature data.

The identified compounds require anti-inflammatory, antiseptic, antispasmodic, analgesic activities of the volatile oil, therefore creation of the medicinal herbal remedy based on the volatile oil of the feverfew herb is prospective. T. parthenium of Ukraine flora can be recommended as an additional source of raw materials for essential oil from herb.

\section{Conflict of interest}

The authors declare that they have no conflicts of interest.

\section{References}

[1] Abad, M. J., Bermejo, P., Villar, A. (1995). An approach to the genusTanacetum L. (Compositae): Phytochemical and pharmacological review. Phytotherapy Research, 9 (2), 79-92. doi: http://doi.org/10.1002/ptr.2650090202

[2] Pareek, A., Suthar, M., Rathore, G., Bansal, V. (2011). Feverfew (Tanacetum parthenium L.): A systematic review. Pharmacognosy Reviews, 5 (9), 103-110. doi: http://doi.org/10.4103/0973-7847.79105

[3] The International Plant Names Index. Available at: https://www.ipni.org

[4] Oladipupo, A. L., Isiaka, A. O., Olusola, F. O., Andy, R. O. (2014). The essential oils of Chrysanthemum morifolium Ramat. from Nigeria. American Journal of Essential Oils and Natural Products, 2 (1), $63-66$.

[5] Ben Sassi, A., Harzallah-Skhiri, F., Chraief, I., Bourgougnon, N., Hammami, M., Aouni, M. (2008). Chemical composition and antimicrobial activities of the essential oil of (Tunisian) Chrysanthemum trifurcatum (Desf.) Batt. and Trab. flowerheads. Comptes Rendus Chimie, 11 (3), 324-330. doi: http://doi.org/10.1016/j.crci.2007.09.006

[6] Mossa, A.-T. H., Mohafrash, S. M. M., Chandrasekaran, N. (2018). Safety of Natural Insecticides: Toxic Effects on Experimental Animals. BioMed Research International, 2018, 1-17. doi: http://doi.org/10.1155/2018/4308054

[7] Guo, S., Geng, Z., Zhang, W., Liang, J., Wang, C., Deng, Z., Du, S. (2016). The Chemical Composition of Essential Oils from Cinnamomum camphora and Their Insecticidal Activity against the Stored Product Pests. International Journal of Molecular Sciences, 17 (11), 1836. doi: http://doi.org/10.3390/ijms17111836

[8] Hordiei, K. R., Gontova, T. M., Zolotajkina, M. Yu., Sira, L. M. (2018). Morphological anatomical signs of the herb of feverfew (Tanacetum parthenium (L.) Schultz Bip.) Pharmaceutical Review, 1, 16-22. doi: http://doi.org/10.11603/ 2312-0967.2018.1.8697

[9] Koshovyi, O. M. (2012). Terpenoidnyi sklad lystia deiakykh predstavnykiv pidrodu Sclarea rodu Salvia. Ukrainskyi biofarmatsevtychnyi zhurnal, 1-2, 77-81.

[10] Osmachko, A. P., Kovaleva, A. M., Ochkur, A. V. (2016). Components of essential oil of Veronica spicata and Veronica chamaedrys L. flowers. American Journal of Science and Technologies, 1 (21 (3)), 1003-1009.

[11] Shafaghat, A., Ghorban-Dadras, O., Mohammadhosseini, M., Akhavan, M., Shafaghatlonbar, M., Panahi, A. (2017). A comparative Study on Chemical Composition and Antimicrobial Activity of Essential Oils fromTanacetum parthenium(L.) Schultz. Bip. and Tanacetum punctatum (Desr.) Grierson. Leaves from Iran. Journal of Essential Oil Bearing Plants, 20 (4), $1143-1150$. doi: http://doi.org/10.1080/0972060x.2017.1383859

[12] Polatoglu, K., Demirci, F., Demirci, B., Gören, N., Baser, K. H. C. (2010). Antibacterial Activity and the Variation of Tanacetum parthenium (L.) Schultz Bip. Essential Oils from Turkey. Journal of Oleo Science, 59 (4), 177-184. doi: http://doi.org/10.5650/jos.59.177

[13] Izadi, Z., Esna-Ashari, M., Piri, K., Davoodi, P. (2010). Chemical Composition and Antimicrobial Activity of Feverfew (Tanacetum parthenium) Essential Oil. International Journal of Agriculture and Biology, 12, 1560-8530.

[14] Mohsenzadeh, F., Chehregani, A., Amiri, H. (2011). Chemical composition, antibacterial activity and cytotoxicity of essential oils of Tanacetum partheniumin different developmental stages. Pharmaceutical Biology, 49 (9), 920-926. doi: http://doi.org/ $10.3109 / 13880209.2011 .556650$ 